\title{
The Development of English Writing Skills Through Techniques of Sentence Skeleton and Signpost Word Analysis for English Major Students
}

\author{
Goachagorn Thipatdee ${ }^{1}$ \\ ${ }^{1}$ Faculty of Education, Ubon Ratchathani Rajabhat University, Thailand
}

Received: January 10, 2019 Accepted: March 5, 2019 Online Published: March 8, 2019

doi: $10.5539 /$ elt.v12n4p32

URL: https://doi.org/10.5539/elt.v12n4p32

\begin{abstract}
The purposes of this research were to develop English writing skills through techniques of sentence skeleton and signpost word analysis for English major students, and to compare the writing skills before and after the study. The sample consisted of 43 English major juniors at Faculty of Education, Ubon Ratchathani Rajabhat University, enrolling in the course of teaching and learning English I, the second semester, academic year 2017, gained by cluster sampling. The research instruments were a performance test of writing skills, and writing drills. The data analyzed by employing percentage, mean, standard deviation, and t-test. After the study, the students had better writing skills with 40.63 percent of average score than those with 14.80 percent before the study, the individual average score was at a weak level with 38.90 percent, while the small group's was at a fair level with 69.78 percent, the individual writing skills were significantly higher than those before the study at the .01 level, and the small group writing skills were significantly higher than those of the individual's at the .01 level.
\end{abstract}

Keywords: English writing skills, sentence skeleton, signpost words

\section{Introduction}

The skills of English writing are said most difficult as Bryan (1987) indicated that writing skills were concerning with tasks, the learners needed to draft or set outlines of what needed to be written, refined the needed data, selected, and arranged them correspondingly to the purpose of effective communication. Due to the difficulty, many foreign learners have faced a large number of problems in writing, as Barra (2001) identified that mistakes often found in English as a foreign language (EFL) writing were spelling, applying of punctuations, content ambiguity and redundancy, based what to write on a mother tongue style, lacking of various types of writing presentation, lacking of content knowledge of written topics, lacking of content cohesiveness, failing to distinguish between facts and opinions, and failing to effectively communicate as expected. In addition, Scott and Tucker (2010) confirmed by their research findings that undergraduate Arabian students who enrolled in the course of intensive English, displayed wrong spoken and written sentences because of mother tongue influences, and errors in analysis of meaning relations. Moreover, Andrian (2015) found similar results since his research revealed that the 17 undergraduate students majoring in office management and computerized information at a business college, made the highest percentage of errors on tenses, and subject verb agreement. Sihombing, Nissa, and Estrelita (2015) also confirmed by their research results that errors were frequently found on syntax and morphology, especially in terms of verb phrase.

Thai students have studied English as a foreign language and a large number of mistakes in writing have been found for about four decades as exemplified by research findings that students taking courses of English aimed to develop their English writing abilities, failed to attain their goals, as Vessakosol (1983) found that the undergraduate students enrolling in the course of English writing I, made errors on lexicon, syntax, and morphology. The most frequent misuses of lexicon were on verbs, syntax on articles, and morphology on tense markers. In addition, Sermsook, Liamnimitr, and Pochakorn (2017) revealed similar results that Thai EFL students frequently made errors in punctuations, articles, subject verb agreement, spelling, capitalization, and fragments. Those who studied in English major and in an international program, made similar mistakes as Khemtong (1981) studied errors in English writing of English major students studying at Ramkhamhaeng University, and found errors in punctuation, vocabulary and idiom usage, spelling, and grammatical structure, respectively. Moreover, Jenwithisook (2007) found that her juniors of international program studying at Rajamangala University of Technology Siwichai misused of determiners, subject and verb agreement, 
prepositions, and tenses.

In the field of Education, serious problems of English learning have not only occurred with those undergraduate students, but also with English Teachers. The information released by the Ministry of Education with the collaboration of the University of Cambridge in a report of Education in Thailand (2012) indicated the results of a field trial that over sixty percent of 400 English teachers had knowledge of the language and teaching methodology below the syllabus levels which they were teaching. It was also found that only twenty percent taught at the levels they were correctly qualified and competent. The field trial revealed more unexpected information when the teachers informed that they were forced to teach English though they had little or no knowledge of the language. This was the results of the debate of academic circles which concluded that teaching English badly during the most influential years of primary level was in fact better than not teaching it.

Based on the above data, it is urgently required that English pre-service teachers must be prepared to solve the mentioned problems. Aimed to improve their English writing skills, the techniques of sentence skeleton and signpost word analysis were applied since the technique of analysis was proved to be effective as Zafar (2016) confirmed her research finding that error analysis marked improvement in the accuracy of the use of verb tenses of her undergraduate students. Moreover, the technique was preferred by EFL students as Karim, Mohamed, Ismail, Shahed, Rahman, and Haque (2018) found their research results that the EFL learners strongly preferred to get their errors corrected by the teachers.

The technique of sentence skeleton, described by Williams (1982), is focusing on identifying basic skeleton of a sentence which is at least to identify the subject and principal verb to comprehend a sentence. For a sentence contains extended subjects, learners need to search for a principal verb, which usually appears late in the sentence, and then find the principal noun, which usually appears early in the sentence, for its subject. He exemplified a sentence of "The pollution of our environment by industrial waste, pesticides, solid wastes and oil spills, all of which have serious and lasting effects, is worrying many scientists.", the verb is "is worrying", so if a question is, what is worrying many scientists?, the answer will be pollution, therefore the subject of the sentence is "pollution".

Williams also explained about signpost words to hint the learners that a text is not unconnected clauses and sentences, but the clauses and sentences cohere like railway carriages, and the words help them cohere are signpost words. He identified twelve kinds of signpost words, which are; however for warning the learners that the line of reasoning is about to change, in fact for introducing specific information, on the contrary for expanding the information, moreover for presenting additional ideas, as a result for introducing the result of the preceding sentence, for example for exemplifying something, in brief for summarizing the preceding reasons, meanwhile for introducing an event that takes place during the preceding event, therefore for reasoning the preceding statement, of course for reminding something already known, in other words for restating the given information, and in conclusion for telling the learners that they reach the end of the line.

Therefore, applying the techniques of sentence skeleton by focusing on analyzing a subject and verb of a sentence, and signpost word analysis, which reminds how sentences are connected, will make different in English writing for the English pre-service teachers.

\section{Method and Material}

\subsection{Research Objectives}

The research objectives were to develop English writing skills through techniques of sentence skeleton and signpost word analysis for English major students, and to compare the students' writing skills before and after the study.

\subsection{Research Design}

The study was pre-experimental design with the pretest and the posttest of a single group without a control group which is called the single group pretest posttest design. After the pretest of writing skills in the first week, the subjects totally took 10 weeks to practice sentence writing. The first and the second weeks were to write compound or complex sentences based on the dictation corresponding to the learning topics. The following weeks were to write compound or complex sentences with the assigned signpost words, and the dictation corresponding to the learning topics.

The subjects were assigned to write the sentences individually and in small groups, but to write paragraphs only in small groups. The paragraph writing practices were on three topics of writing introductory paragraph, writing organizations, and writing conclusion. Week after week, the mistakes of wrong written sentences and sentence connections were analyzed by the whole class before learning a new topic. At the end of the tenth week, the 
subjects took the posttest. The time series of the design illustrated by Table 1 .

Table 1. Time series of the design

\begin{tabular}{lll}
\hline Topics/weeks & Individual writing $(\sqrt{ })$ & Small group writing $(\sqrt{ })$ \\
\hline Pretest & & \\
1.Introduction to sentence skeletons & $\sqrt{ }$ & \\
2.Introduction to signpost words & $\sqrt{ }$ & $\sqrt{ }$ \\
3.Help your child learn English & $\sqrt{ }$ & $\sqrt{ }$ \\
4.Teaching your child listening and speaking skills & $\sqrt{ }$ & $\sqrt{ }$ \\
5.Teaching pronunciation through holistic approach & $\sqrt{ }$ & $\sqrt{ }$ \\
6.Teaching reading through KWL-Plus technique & $\sqrt{ }$ & $\sqrt{ }$ \\
7.Teaching writing & $\sqrt{ }$ & $\sqrt{ }$ \\
8.Writing introductory paragraph & $\sqrt{ }$ & $\sqrt{ }$ \\
9.Writing organizations & $\sqrt{ }$ & \\
10.Writing conclusion & $\sqrt{ }$ & \\
Posttest & &
\end{tabular}

According to Table 1, the subjects had ten-time individual sentence writing, and seven-time small group writing. The small group writing assigned to four-time sentence writing and three-time paragraph writing $(\sqrt{ })$.

\subsection{Population and Sampling Procedures}

The population was 209 English major students studying at the Faculty of Education, Ubon

Ratchathani Rajabhat University, and the sample consisted of 43 juniors enrolling in the course of teaching and learning English I, the second semester of academic year 2017, gained by cluster sampling.

\subsection{Instruments}

The instruments consisted of a writing skill test and writing drills. The test included 30 items of two parts; part one included 15 items of writing for communication in English based on the basic education curriculum (Ministry of Education 2008). The contents focused on daily life communication concerning learner experiences, news, interesting issues, reasoning, food and beverage, personal relationships, leisure and creativities, health, selling and purchasing, weather, education and career, travelling, services, places, science and technology, activities and events occurring in community, local society, and the world; part two included 15 items, assigned to write compound or complex sentences by using the given signpost words. The test is validated by trying it out with the juniors of the Faculty of Humanities, Ubon Ratchathani Rajabhat University, the reliability coefficient was 97 .

The writing drills included two forms of sentence writing; form one is assigned to write compound or complex sentences based on the dictation corresponding to the topics of introduction to sentence skeletons, and introduction to signpost words; form two is assigned to write compound or complex sentences by using the given signpost words based on the dictation corresponding to the topics of help your child learn English, teaching your child listening and speaking skills, teaching pronunciation through holistic approach, teaching reading through KWL-Plus technique, teaching writing, writing introductory paragraph, writing organizations, and writing conclusion.

The scoring rubrics of sentence writing were based on micro aspects (Ur 1996) which include spelling, using punctuations, grammars, and collocations as illustrated in Table 2. 
Table 2. Scoring rubrics for sentence writing

\begin{tabular}{lc}
\hline Score of & Score \\
\hline The sentence shows correct word spelling, punctuations, grammars, and collocations & 1 \\
The sentence shows a mistake of the above components & 0.75 \\
The sentence shows two mistakes of the above components & 0.50 \\
The sentence shows more than two mistakes of the above components & 0.25 \\
The sentence is not completely written, or writing nothing & 0 \\
\hline
\end{tabular}

The paragraph writing scoring rubrics were based on both micro and macro aspects (Ur 1996) as illustrated in Table 3. The collected data were analyzed by employing mean, standard deviation, and t-test. The writing evaluation levels were based on the mastery criteria of 80-100 percent means good, 50-79 percent means fair, and below 50 percent means weak. (Reiser, Driscoll, Farland, Vergara, \& Tessmer 1986)

Table 3. Scoring rubrics for paragraph writing (Total score is 10)

\begin{tabular}{|c|c|c|}
\hline Micro aspects & Scores & Macro aspects \\
\hline $\begin{array}{l}\text { Correct spelling, punctuations, collocations, and } \\
\text { grammars }\end{array}$ & 5 & $\begin{array}{l}\text { Content and organization are coherent and } \\
\text { easy to communicate }\end{array}$ \\
\hline $\begin{array}{l}\text { An error found even on spelling, punctuations, } \\
\text { collocations, and grammars }\end{array}$ & 4 & $\begin{array}{l}\text { An error found even on content or } \\
\text { organization }\end{array}$ \\
\hline $\begin{array}{l}\text { Two to three errors found even on spelling, } \\
\text { punctuations, collocations, and grammars }\end{array}$ & 3 & Some errors found on content or organization \\
\hline $\begin{array}{l}\text { Four to five errors found even on spelling, } \\
\text { punctuations, collocations, and grammars }\end{array}$ & 2 & $\begin{array}{l}\text { Several errors found on content or } \\
\text { organization }\end{array}$ \\
\hline More than 5 errors found & 1 & $\begin{array}{l}\text { Content and organization are not coherent and } \\
\text { difficult to communicate }\end{array}$ \\
\hline
\end{tabular}

\section{Results}

The research findings were displayed on Tables 4 and 5 as follows.

Table 4. The scores and percentage of writing skills $(n=43)$

\begin{tabular}{llccc}
\hline Scores & $x$ & S.D. & Percentage & Meaning \\
\hline Pretest and posttest (Total 30) & & & & Weak \\
Pretest & 4.4419 & 2.19 & 14.80 & Weak \\
Posttest & 12.1919 & 3.95 & 40.63 & Weak \\
Writing scores (Total 10) & & & 38.90 & Fair \\
Individuals & 3.8907 & 1.01 & 69.78 & \\
Small groups & 6.9784 & .36 & & \\
\hline
\end{tabular}

According to Table 4, the mean score of pretest was 4.44, or 14.80 percent, while the posttest score was 12.19 , at 40.63 percent, which was at a weak level. The individual writing mean score was 3.89 , at 38.90 percent, which was at a weak level, but the small groups' was 6.97 , at 69.78 percent, which was at a fair level. 
Table 5. The comparative scores of writing skills $(n=43)$

\begin{tabular}{llll}
\hline Scores & $x$ & S.D. & t-values \\
\hline Pretest writing skills & 4.4419 & 2.19 & $14.62^{* *}$ \\
Posttest writing skills & 12.1919 & 3.95 & \\
\hline Individual writing skills & 3.8907 & 1.01 & $18.90^{* *}$ \\
Small group writing skills & 6.9784 & .36 & \\
\hline
\end{tabular}

$* * \mathrm{p}<0.01$.

According to Table 5, the t-value of pretest and posttest comparison was 14.62, indicated the students had significant higher score of the posttest than that of the pretest at the 0.01 level. It was also found that the $t$-value of 18.90 indicated the small group score was significantly higher than that of the individual's at the 0.01 level.

\section{Discussion}

According to the first research objective, the result indicated the students gained better skills of writing since they got the posttest score at 40.63 percent, which was higher than that of the pretest at 14.80 percent. However, the performance was at a weak level. It might have been because of the difficulty, as identified by Bryan (1987) that writing skills are concerning with tasks, the learners need to draft, or set outlines of what needed to be written, refine the needed data, select, and arrange them correspondingly to the target of effective communication. Therefore the duration of 10 weeks to develop the skills may not have been sufficient for lifting them up to a fair level, as Wiersma (1991) confirmed that the number of observations in series depends on the variables under study, one variation is to increase the number of observations in the series, possibly even as high as 15 or 20 for long-term experiments. Therefore, the posttest level may have been higher if the duration conducted for more time series. The small group writing skills were better than those of the individual's, it might have been because learning together, or cooperative learning is believed to produce better learning outcomes than those of learning alone, as confirmed by Batool (2012), Altun (2015), and Parveen, Yousuf, and Mustafa (2017) which found a similar finding that cooperative learning showed better results for student scholastic accomplishment. Moreover, Andrea and Trivino (2016) conducted a research to see whether cooperative learning can foster the development of adolescents' English writing skills, and the result indicated the subjects performed greater development in English writing.

The findings of the second objective indicated the posttest writing skills were significantly higher than those of the pretest at the 0.01 level, and the small group writing skills were significantly higher than those of the individual's at the 0.01 level, it might have been because the students actively engaged in writing practice as being assigned, therefore they gained better skills due to their active learning. This conclusion confirmed by some research findings, for example, Taraban, Box, Myers, Pollard, and Bowen (2007) conducted their research to find effects of active learning on achievement, and the findings revealed the students gained greater learning compared to traditional instruction. In addition, Eurasia (2007) had his research results concerning the effects of active learning in science education, and the finding revealed the subjects gained positively academic achievement and conceptual development, and had misconceptions in science education at the lowest level. Moreover, Carlson and Winquist (2011) conducted a research to evaluate an active learning approach to teaching introductory statistics, and Dilmac (2016) investigated the effect of active learning techniques on class teacher candidates' success rates, which found similar results that the subjects gained significantly academic achievement, and positive attitude.

According to the techniques of sentence skeleton, and signpost word analysis, there were research findings confirmed that the activities of analyzing writing mistakes or errors, and sentence connections, enhanced the students' academic achievement, as Sunthornwatanasiri (2011) conducted a research concerning application of error analysis to enhance English writing competence of the students majoring in business English, and found the experimental group learning through error analysis gained significantly higher average score of the posttest than that of the control group at the .05 level. In addition, Zafar (2016) confirmed her research finding that the technique of error analysis marked improvement in the accuracy of the use of verb tenses of her undergraduate students.

\section{Conclusion}

The techniques of sentence skeleton and signpost word analysis can enhance the student writing skills because of 
the effective activities of analyzing the mistakes and sentence connections before learning new contents. The techniques are preferably to be applied in EFL writing classrooms since Karim, Mohamed, Ismail, Shahed, Rahman, and Haque (2018) supported that the EFL learners strongly preferred to get their errors corrected by the teachers. It is also concluded that practicing English writing in small groups found to be better than that of individuals. Therefore, the pre-service English teacher writing skills can actually be developed through the techniques, and preferably within fifteen weeks.

\section{Acknowledgement}

I would like to sincerely thank Ubon Ratchathani Rajabhat University for the supporting research budget, the subjects, and those for trying out the instruments.

\section{References}

Altun, S. (2015). The Effect of Cooperative Learning on Students' Achievement and Views on Science and Technology Course. International Electronic Journal of Elementary Education, 7(3), 451-468.

Andrea, P., \& Caicedo, T. (2016). Using Cooperative Learning to Foster the Development of Adolescents' English Writing Skills. Teachers' Professional Development, 18(1), 21-38. https://doi.org/10.15446/profile. v18n1.53079

Andrian, A. (2015). An Error Analysis of EFL Students' English Writing. English Education Journal, 6(4), 511-523.

Barra, A. (2001). Writing: Reflection and Research may Increase Teacher Understanding. Retrieved from $\mathrm{http} / / /$ e.usia.gov/forum $/ \mathrm{htm}$

Batool, S. (2012). Effect of Cooperative Learning on Achievement of Students in General Science at Secondary Level. International Education Studies, 5(2), 154-158.

Bryan, J. (1987). KWL Plus. "KWL Plus: A Strategy for Comprehension and Summarization. Journal of Reading, 7, 626-631.

Carlson, K. A., \& Winquist, J. R. (2011). Evaluating an Active Learning Approach to Teaching Introductory Statistics: A Classroom Workbook Approach. Journal of Statistics Education, 19(1), 1-22. https://doi.org/ 10.1080/10691898.2011.11889596

Dilmac, O. (2016). The Effect of Active Learning Techniques on Class Teacher Candidates' Success Rates and Attitudes toward their Museum Theory and Application Unit in their Visual Arts Course. Educational Sciences: Theory and Practice, 16(5), 1587-1618. https://doi.org/10.12738/estp.2016.5.0108

Education in Thailand. (2012). Wikipedia, the Free Encyclopedia. Retrieved from http://en.wikipedia. org/wiki/Education_in_Thailand

Eurasia, J. M. (2007). The Effects of Problem-Based Active Learning in Science Education on Students' Academic Achievement, Attitude and Concept Learning. Science Technology Education, 3(1), 71-81.

Jenwithisook, T. (2007). A Study of Persisted Errors in Writing of the Third Year Students of English for an International Communication Program. Research Report. Rajamangala University of Technology Siwichai.

Karim, A., Mohamed, A. R., Ismail, S. A. M. M., Shahed, F. H., Rahman, M. M., \& Haque, M. H. (2018). Error Analysis in EFL Writing Classroom. International Journal of English Linguistics, 8(4), 122-138. https://doi.org/10.5539/ijel.v8n4p122

Khemtong, P. (1981). A Study of Errors in Written English of Ramkhamhaeng English Teaching Major Students. Research Report. Ramkhamhaeng University.

Ministry of Education. (2008). Basic Curriculum B.E. 2551. Bangkok: Thailand Agricultural Co-op Club Printing, Ltd.

Parveen, Q., Yousuf, M. I., \& Mustafa, S. (2017). An Experimental Study on the Effect of Cooperative Learning on Students' Academic Achievement and Students' Perceptions towards Cooperative Learning. https://doi.org/10.1080/09720073.2017.1311670

Reiser, R. A., Driscoll, M. P., Farland, D. S., Vergara, A. T., \& Martin, C. (1986). The Effects of Various Mastery Criteria on Student Performance and Attitude in a Mastery-Oriented Course. Educational Technology Research and Development, 34(1), 31-38.

Scott, M. S., \& Richard, T. (2010). Error Analysis and English-language Strategies of Arab Students. 
Sermsook, K. K., Liamnimitr, J., \& Pochakorn, R. (2017). An Analysis of Errors in Written English Sentences: A Case Study of Thai EFL Students. English Language Teaching, 10(3), 101-110. https://doi.org/10.5539/elt. v10n3p101

Sihombing, R., Nissa, A. K.., \& Estrelita, A. (2015). Students' Written Production Error Analysis in the EFL Classroom Teaching: A Study of Adult English Learners Errors. LLT Journal, 18(2), 125-132.

Sunthornwatanasiri, W. (2011). Application of Error Analysis to Enhance English Writing Competence of the Students Majoring in Business English in the Faculty of Business Administration at Rajamangala University of Technology Rattanakosin.

Taraban, R., Box, C., Myers, R., Pollard, R., \& Craig, W. B. (2007). Effects of Active-learning Experiences on Achievement, Attitudes, and Behaviors in High School Biology. Journal of Research in Science Teaching. https://doi.org/10.1002/tea.20183

Ur, P. (1996). A Course in Language Teaching. Cambridge: Cambridge University Press.

Vessakosol, P. (1983). English Writing Abilities of Undergraduate Students Enrolling in English Writing I. Research Report. Thammasat University.

Wiersma, W. (1991). Research Methods in Education: An Introduction (5th ed.). Boston: Allyn and Bacon.

Williams, R. (1982). Panorama An Advanced Course of English for Study and Examinations. London: Longman.

Zafar, A. (2016). Error Analysis: A Tool to Improve English Skills of Undergraduate Students. Procedia-Social and Behavioral Sciences, 217, 697-705. https://doi.org/10.1016/j.sbspro.2016.02.122

\section{Copyrights}

Copyright for this article is retained by the author(s), with first publication rights granted to the journal.

This is an open-access article distributed under the terms and conditions of the Creative Commons Attribution license (http://creativecommons.org/licenses/by/4.0/). 